ISSN 2078-6441. Вісник Львівського університету. Серія географічна. 2014. Випуск 47. С. 292-300. Visnyk of the Lviv University. Series Geography. 2014. Issue 47. P. 292-300.

911.3:008

рисл в имчук

ьвівський н ціон льний університет імені в н вул. . орошенк , 41, 79000, м. ввів, кр їн

озглянуто кл сифік ції суспільно-геогр фічних дисциплін, н ведено їхні спільні т відмінні риси. ростежено місце геогр фії релігії в системі суспільно-геогр фічних н ук. изн чено об'єкт і предмет дослідження геогр фії релігії. ро н лізов но регіон льні розвідки релігійної сфери т систем тизов но підходи до її дослідження.

лючові слов : геогр фія релігії, с кр льн геогр фія, релігійн сфер , соці льн геогр фія, суспільн геогр фія.

елігійн сфер суспільств виконує передусім духовно-культурні функції. плив релігійної сфери охоплює різні спекти життєдіяльності суспільств, формуючи 3 г льносуспільні стереотипи поведінки, тр диції т цінностей. ісце геогр фії релігії в системі суспільно-геогр фічних н ук визн чене об'єктом т предметом дослідження. елігія м є в гоме зн чення в житті суспільств .

еогр фія релігії - це суспільно-геогр фічн н ук, як сформув л ся н стику геогр фії і соціології, вон т кож в жлив для релігієзн вців. ї місце в системі н ук визн чене як об'єктом, т к і предметом дослідження. б'єкт дослідження геогр фії релігії - релігійні орг ніз ції, гром ди і конфесії. обто центром вивчення є людин , їі поведінк, середовище, яке оточує людину, культове місце. ідповідно, предметом є геопросторов орг ніз ція релігійних об'єктів т орг ніз цій у просторі й ч сі в певних природно-, соці льно- т економіко-геогр фічних умов х. еогр фія релігії н лежить до соці льної геогр фії, оскільки з довольняе духовні потреби людини, визн ч є т прогнозує умови і рівень життя суспільств .

кл сифік ції суспільно-геогр фічних дисциплін проф. . блій з г льну теорію суспільної геогр фія поділяє н основні, допоміжні т суміжні дисципліни. сновні дисципліни, відповідно, поділяють н геогр фію н селення, соці льну геогр фію, економічну геогр фію т політичну геогр фію. лузеві скл дові ч стини соці льної геогр фії т кі: геогр фія сфери послуг, геогр фія спожив ння, геогр фія способу життя, геогр фія поведінки т р дик льн геогр фія [14]. певною ч сткою вірогідності сюди, тобто до соці льної геогр фії, н рівні з попередніми геогр фіями, можн 3 числити геогр фію культури, геогр фію релігії (т к зв ну с кр льну геогр фію) н одному рівні з геогр фією н уки і н укового обслуговув ння, геогр фією торгівлі, геогр фією освіти, геогр фією охорони здоров'я т рекре ційною геогр фією.

ісце с кр льної геогр фії визн чене роллю релігії в суспільстві. ому ця г лузь н уки перебув є н стику геогр фії культури і геогр фії сфери послуг. дже с ме релігія є однією з н йв жливіших сфер духовної культури людств , iї функціонув ння - це передусім виробництво і спожив ння с кр льних послуг [13, с. 458].

(C) имчук ., 2014 
структурою суспільної геогр фії проф. . опчієв , з г льн теорія суспільної геогр фії розділен н допоміжні, основні й суміжні дисципліни. сновні дисципліни поділяють н геогр фію н селення, соці льну геогр фію, економічну геогр фію, політичну геогр фію. $\quad$ кр льн геогр фія н лежить до г лузевих дисциплін соці льної геогр фії поряд з геогр фією сфери послуг, геогр фією спожив ння, рекре ційною геогр фією, геогр фією способу життя, гум ністичною геогр фією, р дик льною геогр фією, геогр фією поведінки т геогр фією н уки і культури [11]. редметом геогр фії релігії (с кр льної геогр фії) $є$ територі льн орг ніз ція релігійної життєдіяльності людей т ії вплив н територі льну орг ніз цію суспільств

кщо порівняти ці дві кл сифік ції, з проф. . блієм т проф. . опчієвим, то поб чимо їхню схожість. боє вчених з числяють с кр льну геогр фію до соці льної геогр фії основних дисциплін, і поряд виділяють одні й ті ж н прями соці льної геогр фії. ільки . блій у х р ктеристиці кл сифік ції н одному рівні з геогр фією релігії виділяє геогр фію культури, геогр фію н уки і н укового обслуговув ння, чого не відобр жено н гр фічній моделі.

структурою суспільно-геогр фічних дисциплін проф. . істун поділяє суспільну геогр фію н н літичні (г лузеві), синтетичні, методичні дисципліни. н літичні дисципліни кл сифікують н оцінюв ння природних умов i ресурсів, геогр фію н селення і поселень, геогр фію пр ці, геогр фію промисловості, геогр фію сільського господ рств , геогр фію тр нспорту, геогр фію будівельної індустрії, геогр фію сфери обслуговув ння, геогр фію торгівлі, геогр фію зв'язку, політичну геогр фію, геогр фію культури т геогр фію грошового обігу [9]. кр льну геогр фію цей втор не виділяє. теоретично іiі можн віднести до геогр фії культури, хоч іiі “предметом вивчення є територі льн орг ніз ція культури т їі окремих компонентів - м тері льних і духовних".

структурі н уки “ кономічн і соці льн геогр фія” . оліков, . лійник т . теп ненко виділяють економічну і соці льну геогр фії. оці льну геогр фію розділено н комплексні, г лузево-комплексні і регіон льні н уки. лузевокомплексні н уки структуризов но н політичну геогр фію, геогр фію культури, історичну геогр фію, медичну геогр фію, військову геогр фію, геоінформ тику, геопрогнозув ння, економічну к ртогр фію [1]. чені не виділяють с кр льну геогр фію, чи геогр фію релігії, як с мостійну г лузь, відносять іiі до геогр фії культури.

. юбіцев з зн ч є, що “релігія - суттєв ч стин культури, певною мірою іiі основ . ультур - це скл дне феномен льне і неоднозн чне явище, яке розгляд ють у б г тьох н ук х, чим і пояснюють множинність концепцій культури т ії визн чень” [6, с. 16-17]. “ б’єктом геогр фії релігії є духовн скл дов ноосфери, предметом - 3 кономірності територі льної орг ніз ції релігії в просторі й ч сі в певних природних і соці льно-економічних умов х” [6, с. 18]. “ еогр фія релігій, що вивч $є$ релігійну скл дову підсистеми територі льно-суспільних систем, є розділом геогр фії культури і входить до скл ду суспільно-геогр фічних дисциплін" [6, с. 22]. . юбіцев вв ж є, що геогр фія релігій н лежить до соці льно-геогр фічних дисциплін і є розділом геогр фії культури. езумовно, с кр льн геогр фія є соціогеогр фічною дисципліною. роте з ур хув нням висвітленого вище співвідношення релігії і культури треб кцентув ти ув гу н тому, що з різних поглядів доцільніше розгляд ти с кр льну геогр фію й геогр фію культури як с мостійні соціогеогр фічні н уки. 
кономіст т економіко- і соціогеогр ф. евчук ув ж $\epsilon$, що с кр льн геогр фія - соціогеогр фічн дисциплін . роте, вр ховуючи співвідношення релігії т культури, т кож інші погляди, доцільніше розгляд ти с кр льну геогр фію й геогр фію культури як с мостійні соціогеогр фічні н уки. чен визн ч є, що “об’єктом вивчення с кр льної геогр фії є людин, іiі с кр льний світ т релігійн поведінк, соці льне середовище і релігійні орг ніз ції й культові місця, природне і соці льне середовище, соці льн доктрин еркви тощо, тобто геопросторові форми с кр льних елементів, у тому числі елементів релігії як комплексу об'єктів і явищ, ïх міфології, змісту, генезису, дин міки, ф кторів і з конів формув ння й функціонув ння” [15, с. 14-15]. “ " редмет с кр льної геогр фії - територі льн орг ніз ція с кр льної життєдіяльності людини, релігійної групи людей, кр їни, групи кр їн, світу т іiї вплив н територі льну орг ніз цію суспільств в цілому".

. овенч к поділяє геогр фію культури н етногеогр фію культури, геогр фію релігії т історичну геогр фію культури. думку вченого, с кр льн геогр фія є дещо ширшою, ніж геогр фія релігій (конфесій). ермін “с кр льний” (л т. sacrum, sacri) озн ч є священний, той, що стосується релігійного культу й риту лу. уковець висловив думку, що с кр льн геогр фія, крім конфесійної геогр фії, охоплює т кож геогр фію місць похов нь (некрополів, цвинт рів тощо) [10, с. 129]. дже культур , як відомо з теорії т історії цивіліз ції, почин ється з похов льного обряду.

ольський учений-геогр ф . цковський ув ж є, що геогр фія релігії формується н стику етнології, соціології, релігієзн вств, історії т геогр фічних н ук. еогр фія релігії м є тісні зв'язки з геогр фічними дисциплін ми, с ме - геогр фією людини, геогр фією н селення, геогр фією культури, геогр фією тр нспорту т певною мірою з геогр фією туризму. чений виділяє в геогр фії релігії дв н прями: геогр фію конфесій, бо конфесійну геогр фію т геогр фію п ломництв [16].

ік вим т кож є підхід політико-геогр фів і геополітиків, с ме проф. . ністрянського: "релігійн сфер є в жливим чинником політико-геогр фічної структуриз ції, безпосередньо вплив ючи н держ вно-політичне с мовизн чення, формув ння кордонів держ в, утворення втономій т федер льних кр їв, ст новлення етнополітичних спільнот і центрів" [2, с. 223].

міждисциплін рний н прям у меж х суспільної геогр фії і геогр фії з г лом, який розвив ється н стику геогр фії, релігієзн вств і теології, визн ч є геогр фію релігії вчений-геогр ф . ілоненко [12, с. 4]. г лом “суть геогр фічного вивчення релігії поляг є в тому, що вони розгляд ються як феномен духовного життя людств , н дб ння його культури, що розвив ється в ч сі й просторі і н був є різних проявів: суттєвих т хронохорологічних. к системи духовних цінностей, релігії функціонують у просторі й ч сі, відтворюючись в елемент х м тері льної т духовної культури, н був ючи чинності як мор льно-етичні основи повсякденного людського буття. хня діяльність з безпечує людині можливість з доволення своїх духовних потреб” $[12$, с. 6].

н ш погляд, с кр льн геогр фія, чи геогр фія релігії, - це с мостійн г лузев н ук в скл ді соці льної геогр фії т геогр фії культури, як сформув л ся н стику соціології релігії т геогр фії. он - одн з основних дисциплін суспільної геогр фії.

зн чимо, що геогр фічні дослідження релігійного життя в кр їні впродовж середини-другої половини ХХ ст. були перерв ні політичною ситу цією і поновлені лише н прикінці століття. ершою зн чною пр цею у цьому пл ні був розділ “ еогр фія релігії” . блія в книзі “оці льно-економічн геогр фія кр їни”. чений 
н голосив, що “предметом с кр льної геогр фії є територі льн орг ніз ція релігійного життя і діяльності, з г лом - релігійної сфери. онкретними ре льними об’єкт ми дослідження є геопросторові форми цієї орг ніз ції, зокрем їх морфологія, зміст, генезис, дин мік , ф ктори і з кони формув ння й функціонув ння” [13, с. 458].

ведемо док зи геогр фічності с кр льної, у тому числі й релігійної сфери. погляду суч сної геогр фічної н уки це можн визн чити в т ких спект х:

1) розміщення т поширення релігійних вірув нь і відповідних їм інституцій;

2) н явність геопросторових “фокусів” (“ядер”) релігійного життя т діяльності, які стягують до себе мігр ційні потоки вірних п ломників і рекре нтів (т к зв ні святі місця; постольські столиці; місця чудотворних ікон чи обр зів, н прикл д, “ікон ожої тері у енстохові" в ольщі; місця прояву “небесних чудес", як це було у с. рушів н ьвівщині н прикінці 80-х років тощо);

3) розвиток територі льної с кр льної інфр структури, як з безпечує духовну сферу послуг ми (виробництво церковного н чиння т одягу, вид ння релігійної літер тури і релігійне мистецтво, зокрем, н пис ння ікон; підготовк служителів культу - осіб духовного с ну; створення, розвиток т впров дження спеці льних з собів м сової інформ ції тощо);

4) $з$ лежність територі льної диференці ції релігійного життя т діяльності від геопросторових відмінностей у демогр фічній i природно-геогр фічній оболонці $[15$, с. 13].

еоретичну т методичну б зу суспільно-геогр фічних регіон льних досліджень релігійної сфери розробляють т кі вчені-геогр фи, як . блій, . опчієв, . істун, · оліков, · лійник, · теп ненко, · юбіцев , · евчук, · овенч к, . ністрянський. оглибленим вивченням с кр льної геогр фії н регіон льному рівні з йм ються . тійчук, . влов, . уч бський, . лючко, . ог тько т ін. н слідок проведеного дослідження . тійчук у дисерт ційній роботі “ ериторільн орг ніз ція релігійної сфери дміністр тивної обл сті (н прикл ді олинської обл сті)" поглибив теоретичні основи суспільно-геогр фічного вивчення територі льної орг ніз ції релігійної сфери. перше він провів комплексне дослідження територі льної орг ніз ції релігійної сфери дміністр тивної обл сті, що д ло змогу з позицій системно-структурного н лізу розвинути концепцію впливу геогр фічних умов і чинників н формув ння територі льно-релігійної системи дміністр тивної обл сті т виявити елементи її функціон льної структури і викон ти їхній н ліз. дисерт ції розкрито основні проблеми функціонув ння територі льно-релігійної системи і територі льної орг ніз ції релігійної сфери олинської обл. з г лом, н мічено способи їхнього вирішення з метою відродження духовності н селення т в кінцевому підсумку - підвищення рівня соці льно-економічного розвитку регіону. ослідження функціон льно-територі льної структури територі льно-релігійної системи олинської обл. д ло змогу визн чити іï елементи і провести їхню типіз цію. обудов но к ртогр фічні моделі територі льної структури територі льно-релігійної системи ( $г$ г олинської обл. т лок ліз ції об'єктів релігійного обслуговув ння н селення. пропонов но способи подол ння міжконфесійних конфліктів у олинській обл. [8, с. 3].

влов у дисерт ційному дослідженні “ рг ніз ція релігійно-геогр фічної сфери

кр їни” головну ув гу приділив виявленню 3 кономірностей вз ємного впливу релігійної сфери т інших компонентів суспільно-геогр фічного комплексу н різних т ксономічних рівнях. озроблено методику дослідження георелігійної ситу ції, про н лізов но процеси і тенденції, що відбув ються в релігійно-геогр фічній сфері н 
з г льнодерж вному т регіон льному рівнях. обудов но низку ситу ційних моделей окремих територі льних конфесійних систем т проведено релігійно-геогр фічне р йонув ння кр їни [6, с. 2-3].

ідходи вторів до дослідження релігійної сфери регіонів

\begin{tabular}{|c|c|c|c|}
\hline $\begin{array}{c}\text { в тор, } \\
\text { н зв } \\
\text { дисерт ції, } \\
\text { рік }\end{array}$ & $\begin{array}{c}\text { тійчук } \\
\text { “ ериторі льн орг ніз ція } \\
\text { релігійної сфери дміністр тив- } \\
\text { ної обл сті (н прикл ді } \\
\text { олинської обл сті)”, } 1998\end{array}$ & $\begin{array}{c}\text { “ } \quad \text { влов } \\
\text { рг ніз ція релігійно- } \\
\text { геогр фічної сфери } \\
\text { кр їни”, } 1999\end{array}$ & \begin{tabular}{|c} 
у уч бський \\
“ елігійн сфер обл сного \\
регіону: тр нсформ ція і \\
територі льн орг ніз ція (н \\
м тері л х ьвівської \\
обл сті)”, 2000 \\
\end{tabular} \\
\hline $\begin{array}{l}\text { ериторі льні } \\
\text { м сшт бні } \\
\text { дослідження } \\
\end{array}$ & бл сть & $\mathrm{p}$ ïH & бл сть \\
\hline $\begin{array}{c}\text { ериторі ль- } \\
\text { ний розріз } \\
\text { дослідження } \\
\end{array}$ & йони & бл сті & йони, гром ди \\
\hline б'€KT & $\begin{array}{l}\text { ериторі льно-релігійн систем } \\
\text { олинської обл., для якої х р к- } \\
\text { терний інтенсивний прояв релі- } \\
\text { гійного життя й діяльності н се- } \\
\text { лення в кр їні, поліконфесій- } \\
\text { ність, що скл л ся історично, } \\
\text { ун слідок прикордонного розт - } \\
\text { шув ння т під впливом інших } \\
\text { суспільно-геогр фічних умов }\end{array}$ & $\begin{array}{l}\text { елігійно-геогр фічн сфер } \\
\text { кр їни, скл дов сфер ду- } \\
\text { ховної культури, компо- } \\
\text { ненти т функціон льні еле- } \\
\text { менти якої, пройшовши ет - } \\
\text { пи ст новлення, функціону- } \\
\text { в ння і розвитку, певним } \\
\text { чином лок лізов ні й функ- } \\
\text { ціонують у просторі } \\
\end{array}$ & $\mid \begin{array}{lll}\text { елігійн } & \text { сфер обл сного ре- } \\
\text { гіону } & \text { кр іни } & \text { ( ьвівсь- } \\
\text { к обл.) } & & \\
& & \end{array}$ \\
\hline редмет & $\begin{array}{l}\text { ивчення з кономірностей і } \\
\text { проблем територі льної орг ні- } \\
3 \text { ції релігійної сфери дміністр - } \\
\text { тивної обл сті як скл дової } \\
\text { духовності н селення т необ- } \\
\text { хідної умови підняття рівня соці- } \\
\text { льно-економічного розвитку } \\
\text { регіону }\end{array}$ & $\begin{array}{l}\text { хоплює три рівні функціо- } \\
\text { нув ння } \quad: \text { верхній - } \\
\text { ідеологічний, середній - со- } \\
\text { ці льний, нижній - л нд- } \\
\text { ш фтний }\end{array}$ & $\begin{array}{l}\text { ериторі льн орг ніз ція ре- } \\
\text { лігійної сфери ьвівсь- } \\
\text { кої обл., особливості ії фор- } \\
\text { мув ння і функціонув ння в } \\
\text { період структурної тр нсфор- } \\
\text { м ції, т кож чинники т } \\
\text { передумови, які вплив ють н } \\
\text { розвиток релігійної сфери, їі } \\
\text { територі льну орг ніз цію в } \\
\text { перехідний період } \\
\end{array}$ \\
\hline $\begin{array}{c}\text { диниці } \\
\text { дослідження }\end{array}$ & елігійні гром ди & онфесії, релігійні гром ди & \\
\hline $\begin{array}{c}\text { ідходи до } \\
\text { дослідження }\end{array}$ & истемно-структурний & $\begin{array}{l}\text { етодологічним підходом є } \\
\text { метод георелігійної ситу ції } \\
\text { у поєдн нні } 3 \text { системно- } \\
\text { структурним }\end{array}$ & \\
\hline $\begin{array}{c}\text { етоди } \\
\text { дослідження }\end{array}$ & $\begin{array}{l}\text { • суспільно-геогр фічне } \\
\text { р йонув ння, } \\
\text { • ст тистичний, } \\
\text { • порівняльно-геогр фічний, } \\
\text { • економіко-м тем тичний, } \\
\text { • } 6 \text { л нсовий, } \\
\text { • гр фічний, } \\
\text { • к ртогр фічний, } \\
\text { • експедиційний, } \\
\text { • соціологічний }\end{array}$ & $\begin{array}{l}\text { • м тем тичне моделюв ння, } \\
\text { • м тем тико- } \\
\text { к ртогр фічний, } \\
\text { • історико-геогр фічний, } \\
\text { • р йонув ння, } \\
\text { • порівняльний }\end{array}$ & $\begin{array}{l}\text { ілософські, з г льнон укові, } \\
\text { конкретнон укові: } \\
\text { • польовий; } \\
\text { • нкетний; } \\
\text { • інтерв'юв ння; } \\
\text { • м тем тичний; } \\
\text { • ст тистичний; } \\
\text { • к ртогр фічний; } \\
\text { • релігійно-геогр фічне } \\
\text { р йонув ння }\end{array}$ \\
\hline
\end{tabular}


кінчення т бл.

\begin{tabular}{|c|c|c|}
\hline $\begin{array}{l}\text { в тор, н зв } \\
\text { дисерт цї̈, } \\
\text { рік }\end{array}$ & $\begin{array}{c}\text { • лючко } \\
\text { “ ериторі льн орг ніз ція релігійної сфери } \\
\text { рківського регіону”, } 2010\end{array}$ & \begin{tabular}{|c}
\multicolumn{1}{c}{ ог тько } \\
“ успільно-геогр фічне дослідження \\
релігійної діяльності т с кр льних просторів \\
ернігівської обл сті”, 2011
\end{tabular} \\
\hline $\begin{array}{l}\text { ериторі льні } \\
\text { м сшт бні } \\
\text { дослідження }\end{array}$ & бл сть & бл сть \\
\hline $\begin{array}{l}\text { ериторі ль- } \\
\text { ний розріз } \\
\text { дослідження }\end{array}$ & йони & йони \\
\hline б'єKт & елігійн сфер регіон льної соціогеосистеми & $\begin{array}{l}\text { елігійн діяльність т с кр льні простори } \\
\text { ернігівської обл. }\end{array}$ \\
\hline редмет & $\begin{array}{l}\text { росторово-ч сові особливості розвитку релі- } \\
\text { гійної сфери рківського регіону як в жли- } \\
\text { вого чинник формув ння соціуму }\end{array}$ & $\begin{array}{l}\text { успільно-геогр фічні особливості розвитку } \\
\text { релігійної діяльності т використ ння с к- } \\
\text { р льних просторів ернігівської обл. }\end{array}$ \\
\hline $\begin{array}{c}\text { диниці } \\
\text { дослідження }\end{array}$ & $\begin{array}{l}\text { елігійні гром ди, релігійні орг ніз ції т } \\
\text { конфесії }\end{array}$ & елігійні гром ди, конфесії \\
\hline $\begin{array}{c}\text { ідходи до } \\
\text { дослідження }\end{array}$ & & $\begin{array}{l}\text { - елігійно-геогр фічне р йонув ння, } \\
\text { • дослідження с кр льності у л ндш фтному } \\
\text { вимірі т вивчення с кр льних просторів, } \\
\text { • геогр фічне дослідження релігійного туриз- } \\
\text { му т п ломництв , } \\
\text { • дослідження конфесійної структури т релі- } \\
\text { гійності в політичній геогр фії }\end{array}$ \\
\hline $\begin{array}{c}\text { етоди } \\
\text { дослідження }\end{array}$ & $\begin{array}{l}\text { г льнон укові, міждисциплін рні, спеці льні } \\
\text { - синтез, н ліз, індукція, дедукція, літер - } \\
\text { турний, уз г льнення; } \\
\text { • ст тистичний м тем тико- н літичний, } \\
\text { - системно-структурний, к ртогр фічний, іс- } \\
\text { торико-геогр фічний, моделюв ння, порів- } \\
\text { няльно-геогр фічний }\end{array}$ & $\begin{array}{l}\text { ореляційний, системно-структурний н ліз } \\
\text { • історико-геогр фічних зрізів, ретроспектив- } \\
\text { ний, генетичний, к ртогр фічний, } \\
\text { • системно-структурний н ліз, ст тистичний, } \\
\text { розр хунковий, р йонув ння, к ртогр фічний, } \\
\text { центрогр фічний, експертних оцінок }\end{array}$ \\
\hline
\end{tabular}

дисерт ції . уч бського “ елігійн сфер обл сного регіону: тр нсформ ція і територі льн орг ніз ція (н м тері л х ьвівської обл сті)” уз г льнено н уковометодичні з с ди регіон льного релігійно-геогр фічного дослідження, 3 пропонов но нові підходи до дослідження проблем тр нсформ ції релігійної сфери т їі територі льної орг ніз ції в конкретному регіоні ( ьвівськ обл.); виявлено т про н лізов но зв'язок релігійної сфери з іншими сфер ми суспільного життя т діяльності, природногеогр фічним середовищем тощо; н прикл ді ьвівської обл. викон но н ліз особливостей формув ння регіон льної територі льної релігійної системи; досліджено особливості міжконфесійних стосунків у ьвівській обл. т їхній вплив н територі льну орг ніз цію окремих конфесій; обгрунтов но територі льну орг ніз цію релігійної сфери ьвівської обл.; удоскон лено методику релігійно-геогр фічних досліджень, д но рекоменд ції шодо систем тиз ції т опр цюв ння джерел для дослідження релігійної сфери обл сного регіону. окрем , уперше в пр ктиці вітчизняних релігійногеогр фічних досліджень використ но метод нкетув ння н селення ьвівської обл. як цілісної територі льної структури [5, с. 2]. пропонов но методичні нововведення, які д ли змогу суттєво поліпшити якість отримув них результ тів. окрем , 3 метою усунення помилки репрезент тивності з пропонов но метод верифік ції результ тів нкетув ння. 
дослідженні . лючко “ ериторі льн орг ніз ція релігійної сфери рківського регіону” визн чено особливості просторового розподілу елементів релігійної сфери рківського регіону для н йчисленніших конфесій з погляду суспільної геогр фії. пропонов но соці льно-геогр фічне визн чення індик тивної функції релігії як з собу відобр ження ступеня збурення соціуму, т мент літетної функції як чинник формув ння його духовності. икон но н ліз формув ння конфесійного скл ду релігійної сфери рківського регіону, зокрем , з'ясов но, що н розвиток релігійних гром д суттєво вплив ють історичний т соці льно-геогр фічні чинники [3, с. 2-3]. икон но систем тиз цію і групув ння р йонів рківського регіону з особливостями розвитку релігійної сфери.

. ог тько у дисерт ції “ успільно-геогр фічне дослідження релігійної діяльності т с кр льних просторів ернігівської обл сті” виявив особливості георелігійної ситу ції в ернігівській обл., зокрем , з'ясов но, що для регіону х р ктерн поліконфесійність з домінув нням пр восл вних релігійних гром д, дин мічність бсолютних пок зників розвитку георелігійного процесу т стійкістю центрів в ги релігійних гром д; територі льн концентр ція релігійних гром д т відповідність їхнього територі льного розподілу розміщенню н селення регіону. н слідок історикогеогр фічного н лізу виділено ет пи розвитку георелігійного процесу в ернігівській обл. в розрізі пр восл в'я т інших релігійних н прямів і конфесій. індексом інтенсивності релігійної діяльності виділено ядр релігійної діяльності в ернігівській обл., т кож викон но релігійно-геогр фічне р йонув ння обл сті, зокрем виділено п'ять релігійних р йонів: ернігівський, овгород- іверський, озелецький, іжинський i рилуцький. изн чено проблеми суч сної георелігійної ситу ції в ернігівській обл. т 3 пропонов но способи їхнього вирішення [4, с. 2-3].

пр цях дослідників головним об’єктом дослідження є релігійн сфер регіону,

т кож релігійн діяльність т с кр льні простори (див. т блицю). егіони й спекти досліджень у розрізі території вивчено з дміністр тивними одиницями - обл стями і кр їн ми.

ідходи до дослідження релігійної сфери є різні, зокрем - системно-структурний ( . тійчук) т метод георелігійної ситу ції в поєдн нні з системно-структурним ( . влов). б'єкти дослідження різних вторів т кі:

1) територі льно-релігійн систем , для якої х р ктерні інтенсивний прояв релігійного життя й діяльності н селення в кр їні, поліконфесійність, що скл л ся історично, ун слідок прикордонного розт шув ння т під впливом низки інших суспільногеогр фічних умов;

2) релігійно-геогр фічн сфер ( ) кр їни, скл дов сфер духовної культури, компоненти т функціон льні елементи якої, пройшовши ет пи ст новлення, функціонув ння і розвитку, певним чином лок лізов ні й функціонують у просторі;

3) релігійн сфер регіон льної соціогеосистеми;

4) релігійн діяльність т с кр льні простори ернігівської обл.

редмети досліджень різном нітні й охоплюють великий ді п зон спектів, с ме:

1) вивчення з кономірностей і проблем територі льної орг ніз ції релігійної сфери дміністр тивної обл сті як скл дової духовності н селення т необхідної умови підняття рівня соці льно-економічного розвитку регіону;

2) три рівні функціонув ння : верхній - ідеологічний, середній - соці льний, й нижній - л ндш фтний; 
3) просторово-ч сові особливості розвитку релігійної сфери рківського регіону як в жливого чинник формув ння соціуму;

4) суспільно-геогр фічні особливості розвитку релігійної діяльності т використ ння с кр льних просторів ернігівської обл.

жливим методологічним підходом до дослідження релігійної сфери є метод георелігійної ситу ції в поєдн нні з системно-структурним підходом, який у своїй дисерт ційній роботі “ рг ніз ція релігійно-геогр фічної сфери кр їни” використ в влов.

елігійну сферу можн віднести до н йбільш консерв тивних сфер суспільств . он в жлив для н ціон льних інтересів кр їни. еобхідною умовою розбудови демокр тичної держ ви є н ціон льні інтереси, особливо інтереси в релігійній сфері, які потрібно визн ч ти винятково волевиявленням н роду безпосередньо бо через вищі інституції держ вної вл ди. р ховують принцип відокремлення церкви від держ ви як в жливу конституційну демокр тичну з с ду, вз ємовідносин держ ви і релігійних орг ніз цій, умову т г р нтію свободи совісті.

тже, н н ш погляд, предметом регіон льних досліджень релігійної сфери є геопросторов орг ніз ція релігійних утворень у просторі й ч сі, тобто конфесій як певних інститутів у суспільстві, що сформув лися під впливом сповідув ння спільних релігійних світоглядів. ериторі льні м сшт би цих досліджень розуміють як проміжні між глоб льним і лок льним рівнем. елігійні орг ніз ції і релігійні гром ди є відобр женням цих соці льних інститутів у документ х звіту деп рт менту релігій і н ціон льностей. озміщення т поширення релігійних вірув нь і відповідних їм інституцій, формув ння ядер релігійного життя і діяльності, які стягують н себе мігр ційні потоки вірних, п ломників. озвиток територі льної релігійної інфр структури, як з безпечує духовну сферу послуг ми (виробництво церковного одягу, вид ння релігійної літер тури, н пис нням ікон, підготовк служителів культу - осіб духовного ст ну). лежність територі льної диференці ції релігійного життя від територі льних відмінностей в етно-, демо- т природно-геогр фічному оточенні.

1. оліков . . ступ до економічної і соці льної геогр фії / . . оліков, . . лійник, . . теп ненко. - . . ибідь, 1996. - 320 с.

2. ністрянський . . олітичн геогр фія і геополітик кр їни : н вч. посібник / . . ністрянський. - ернопіль: вч льн книг - огд н, 2010.-344с.

3. лючко . . ериторі льн орг ніз ція релігійної сфери рківського регіону : втореф. дис. н здобуття н ук. ступеня к нд. геогр. н ук / . . лючко. ., $2010 .-20 \mathrm{c}$.

4. ог тько . . успільно-геогр фічне дослідження релігійної діяльності т с кр льних просторів ернігівської обл сті : втореф. дис. н здобуття н ук. ступеня К нд. геогр. н ук / . . ог тько. - ., 2011. - 20 с.

5. уч бський . . елігійн сфер обл сного регіону : тр нсформ ція і територі льн орг ніз ція (н м тері л х ьвівської обл сті) : втореф. дис. н здобуття н ук. ступеня к нд. геогр. н ук / . . уч бський. - ьвів : ім. . p нК , 2000. -20 с.

6. влов . . еогр фія релігій / . . влов, . . езенцев, . . юбіцев . .: рт к, 1998. $-504 \mathrm{c}$. 
7. влов . . рг ніз ція релігійно-геогр фічної сфери кр їни: втореф. дис. н здобуття н ук. ступеня к нд. геогр. н ук / . влов. - ., 1999. - 20 с.

8. тійчук . . ериторі льн орг ніз ція релігійної сфери дміністр тивної обл сті (н прикл ді олинської обл сті) : втореф. дис. н здобуття н ук. ступеня к нд. геогр. н ук / . . тійчук. - уцьк, 1998. - 20 с.

9. істун . . снови теорії суспільної геогр фії / . . істун. - . : ищ школ , 1996. $-232 \mathrm{c}$.

10. овени к.. еогр фія культури : проблеми теорії, методології т методики дослідження / . . овенч К. - ьвів : ім. . p нК , 2008. - 240 с.

11. опчієв . . снови суспільної геогр фії / . . опчієв. - дес : стропринт, 2009. $-560 \mathrm{c}$

12. ілоненко . . еогр фія релігії / . . ілоненко. - іжин : ім. . оголя, 2006. $-256 \mathrm{c}$.

13. блій . . еогр фія релігії // оці льно-економічн геогр фія кр їни / з ред. блія. - ьвів : віт, 1994. - .457-474.

14. блій . снови суспільної геогр фії / . . блій. - ьвів : ім. . p нк , 2012. -244 c.

15. евчук . . кр льн геогр фія : н вч. посібник / . . евчук. - ьвів : віт, 1999. - $160 \mathrm{c}$.

16. Jackowski A. Święta przestrzeń świata. Podstawy geogerafii religii / A. Jackowski. Kraków : WUJ, 2003. - $268+32$ s.

m ття: н дійшл до ред кцї 20.06.2014

доопр иьов н 19.08 .2014

прийнят до друку 10.09.2014

\section{SOCIAL AND GEOGRAPHICAL ESSENCE OF REGIONAL RESEARCH OF RELIGIOUS SPHERE}

\section{Oryslava Tymchuk}

Ivan Franko National University of Lviv, P. Doroshenko Str., 41, UA - 79000 Lviv, Ukraine

The classification of human geographical subjects, their common and distinctive features has been noted. The place of geography of religion in the system of human geographical sciences has been traced. The object and subject of study of geography of religion has been identified. The regional investigations of sphere of religion have been analysed and approaches to its study have been systemized.

Key words: geography of religion, sacred geography, religious sphere, social geography, human geography. 